are, in our opinion, their most easily recognized distinctions. The melting-point test by itself, as already pointed out by Brown, Morris and Miller, ${ }^{1}$ is unreliable, and has led to serious errors of identification. This is due to the slight differences in the values in the case of many of the sugars, the difficulty in getting the exact melting-points owing to decomposition, and the great influence of very small amounts of impurities difficult to remove.

SUgAR IABORATORY, MASS. INST.

OF TECHNOLOGY.

\title{
A STUDY IN RAFFINOSE DETERMINATIONS.
}

\author{
By David L, Davoll, JR. \\ Received July 23, 1903.
}

THE existence of several methods for the determination of raffinose in the presence of saccharose, together with variable results obtained in the application of the same to the analysis of the same product, have impelled me to investigate the matter more closely after the close of the "campaign." As the result of a study of the various methods, I have been led to combine the best features of some of them and believe that I have succeeded in applying a slight modification to the method of Clerget, which will secure for it accurate and satisfactory results with darkcolored products. The modification proposed is that of applying powdered zinc after inversion and at the temperature of inversion, with the production of an almost colorless solution with no change in the products of the hydrolysis of either sucrose or raffinose.

As the basis of these experiments a pure, doubly refined, white sugar, of undoubted cane origin, was employed and a commercial sample of raffinose from the house of Kahlbaum. The canesugar was perfectly free from invert-sugar and polarized 99.97 per cent. pure after being powdered and dried at a temperature of $60^{\circ}-70^{\circ} \mathrm{C}$.

The one sample of molasses was employed throughout the work.

Three samples of animal charcoal were purchased from a reliable Chicago firm and in original packages as bottled by the German firms of Merck and Dr. König. These chars were dried to constant weight before use at a temperature between I I $5^{\circ}$ and

'J. Chem. Soe. (London), 67, 709: "The Isomaltose of C. J. Lintner." 
$125^{\circ} \mathrm{C}$. It is important to know that the moisture content of these chars varied from 7.17 per cent. to 25.7 per cent.

The modern double-field $\mathrm{S}$. and $\mathrm{H}$. instrument employed was very recently checked by means of a quartz plate kindly loaned by the Division of Chemistry, U. S. Dept. of Agriculture, Washington, D. C., and all important points on the scale verified by a pure sugar standardized against the quartz of 90 per cent. polarization. 'The levo-rotation, when checked against the dextrorotation, gave the same figure in every instance. The flasks used were all restandardized to hold Ioo Mohr cc. All polarizations, both direct and invert, were made in the same jacketed 200 mm. tube and at the standard temperatures of $17.5^{\circ} \mathrm{C}$. (for direct) and $20^{\circ} \mathrm{C}$. (for inverted) so as to avoid all corrections for variation in specific rotation. The readings as given are averages of at least five separate rereadings.

Some work by G. Reinhardt, ${ }^{1}$ calling attention to the often increased levo-rotation where char is used for decolorizing "rest" molasses arising from strontium juices, has impelled me to apply the samples of char mentioned for the purpose of reviewing his findings. Reinhardt mentions that bone-black has been regarded, up to the present time, as diminishing levo-rotation by absorption, while blood-char, in spite of its superior decolorizing power, had to be given up because of high absorption.

Following are our results in determining the effect of char upon a solution of pure cane-sugar after hydrolysis by the strict method of Clerget.

(I) Carbo Sanguinis, acido depur, pro analyse. Dr. König.......... - $16.4 \mathrm{I}$ Calculated
normal basi6.

$$
\begin{gathered}
\text { Original } \\
\text { polarization. }
\end{gathered}
$$

(2) Animal charcoal, Merck, highest purity, dry .............. -16.29

(3) Animal charcoal, Merck, reagent.

$-16.2 \mathrm{I}$

$-32.42$

I have not found the levo-rotation diminished by Carbo Sanguinis, but rather slightly increased. Three grams of all chars were used and the vigorous shaking continued five minutes, with three minutes allowed for filtration. Reinhardt found slight diminution, increasing with blood char.

1 G. Reinhardt, I902 : "Ueber Raffinosebestimmungen," Zlschr. d. Ver. für d. Rübenzuckerind. d. deutsch. Reiches, 2 , II4. 
Dr. G. Wiske ${ }^{1}$ has elaborated Reinhardt's investigation, working also with dextrose, levulose and galactose in their separate behavior toward chars. Differing with Reinhardt, he finds absolutely no absorption or change when char is applied five minutes to inverted pure sucrose. He explains this invariability by showing in a test with equivalent quantities of levulose and dextrose that the notable absorption of dextrose, together with small absorption of levulose, mutually counteract any error. Where raffinose is present the results are different.

Reinhardt has shown that with rising raffinose content there is increased levo-rotation. In the case of bright after-products having 2.5 per cent. raffinose and using 3 grams of "Klaerkohle" he found the same levo-rotation. He explains this by saying that the absorptive power which diminishes the levo-rotation in the case of inverted pure saccharose is compensated by the simultaneous increase in levo-rotation of inverted rafinose; also due to absorption; hence, where 2.5 per cent. raffinose is present the results are correct, while with less than 2.5 per cent. too little saccharose and too much raffinose is found, though the error is small, while with more than 2.5 per cent. raffinose, too much saccharose and too little raffinose is found. Reinhardt further considers that high levo-rotation is due to absorption of dextro-rotatory melibiose, but he awaits further investigation.

Wiske has also imitated a mixture of raffinose and saccharose by inverting and polarizing a mixture of saccharose, levulose and melibiose, finding a very strong increase in levo-rotation with use of char. In experiments upon mixtures of saccharose and raffinose as they occur 'in after-product massecuites, sugars and "rest" molasses, he finds the degree of absorption to be entirely dependent upon the quantity of raffinose and indifferent to the quantity of saccharose. Employing half-normal and 3 grams char, he recommends a subtractive correction of $1 /{ }_{10}$ degree for every per cent. of raffinose above 2 per cent.

To ascertain the comparative effect of the three varieties of char upon hydrolyzed mixtures of pure cane-sugar and raffinose, 12.367 grams cane-sugar and 0.657 gram raffinose were hydrolyzed in $75 \mathrm{cc}$. dilution, according to the strict Clerget method, shaking five minutes with 3 grams char and filtering two to three

1 G. Wiske, I902: "Ueber Raffinosebestimmungen," Ztschr.d. Ver. fürd. Ruebenzuckerind. d. deutschen Reiches. 
minutes. The direct polarization of a normal solution of such a mixture was 102.48 per cent.

Polarization without char..... - I $_{3.50} \quad-27.00 \quad 4.16 \quad 94.77$

(I) Carbo Sanguinis, acido depur.

proanalyse. Dr. König … $-13.57 \quad-27.14 \quad 4.11 \quad 94.87$

(2) A nimal charcoal, Merck, highest

purity, dry............. $-13.70 \quad-27.40 \quad 3.95 \quad 95.16$

(3) Animal charcoal, Merck, reagent $\begin{array}{llll}-14.00 & -28.00 & 3.5^{6} & 95.89\end{array}$

The samples of blood-char, under the conditions, produced a levo-rotation that results in a raffinose content not far removed from polarization without char, which may be explained by the absorption of dextro- and levo-rotatory substances, mutually offsetting each other.

A notable increase in levo-ratation will be shown later in further comparative tests.

The effect of time as a factor in decolorizing, is shown where Merck's highest purity char is used upon the molasses :

\begin{tabular}{|c|c|c|c|c|c|}
\hline $\begin{array}{l}\text { Time of char } \\
\text { digestion. } \\
\text { Minutes. }\end{array}$ & $\begin{array}{l}\text { Filtra- } \\
\text { tiont. } \\
\text { Minutes. }\end{array}$ & $\begin{array}{c}\text { Original } \\
\text { polarization. }\end{array}$ & $\begin{array}{l}\text { Calculated } \\
\text { normal. }\end{array}$ & Raffinose. & Sucrose \\
\hline 5 & 7 & -5.48 & --10.96 & $3.5^{8}$ & 43.97 \\
\hline$\ldots$ 10 & 9 & $-5.5 \mathrm{I}$ & $-\mathrm{I} I, 02$ & 3.54 & 44.04 \\
\hline ... 15 & 9 & -5.55 & -IIIO & 3.49 & 44.13 \\
\hline Decolorat & by zinc & -5.48 & -10.96 & $3.5^{8}$ & 43.97 \\
\hline
\end{tabular}

The decoloration after fifteen minutes, while slightly more than that of five minutes, was not worthy of consideration. The result in (4) is that obtained by the action of I gram powdered zinc for three to four minutes at $69^{\circ} \mathrm{C}$. after completion of inversion by the strict method of Clerget and is the modification I would propose as a solution of the vexatious problem of bleaching. It is added here for the sake of comparison and will be referred to later. The direct polarization of this molasses was 50.6 per cent., using lear! - $b$ - acetate as a precipitant, with and without acetic acidulation, producing identical results in polarization.

The method of Lindet as modified by Courtonne was examined, but gave such widely varying resuts with a mixture of pure canesugar and raffinose that the results obtained upon a low product, like molasses, may be credited with difficulty. The method is as follows : $20 \mathrm{cc}$. of a solution containing $1 / 5$ normal of the substance is placed in a $50 \mathrm{cc}$. flask, and 5 grams of zinc dust, accurately weighed, are placed in the flask. Heat the flask and con- 
tents by immersing in boiling water. Add Io $\mathrm{cc}$, of dilute hydrochloric acid in portions of about $2 \mathrm{cc}$. at a time and as frequently as convenient. Prepare the dilute acid by adding to pure hydrochloric acid (sp. gr. 1.2) an equal volume of distilled water. Heat a few minutes after the last addition of acid. The undecomposed zinc occupies a volume of $0.5 \mathrm{cc}$. ;hence, the normal invert reading is obtained by multiplying by 2.475 . After the inversion is completed, cool the solution, either quickly or slowly, by setting aside. Complete the volume at $20^{\circ} \mathrm{C}$. Mix, filter and polarize at $20^{\circ} \mathrm{C}$.

In his original article, Lindet directs that $5 \mathrm{cc}$. concentrated hydrochloric acid be gradually added in 4 or 5 parts at intervals of five minutes, and that the zinc be filtered off before dilution to $50 \mathrm{cc}$. A formula is given for use with the Laurent instrument. Spencer ${ }^{1}$ gives a formula for use with the $\mathrm{S}$. and $\mathrm{H}$. instrument as follows :

(I) Sucrose $=\frac{\mathrm{C}-0.493 \mathrm{~A}}{0.827} \quad$ (2) Raffinose $=\frac{\mathrm{A}-\text { Sucrose }}{\mathrm{I} .85}$ where $\mathrm{A}=$ the direct reading, and $\mathrm{C}=$ algebraic sum of direct and invert reading.

For convenience, all calculations based upon formulas (I) and (2) will be designated "Lindet" merely to distinguish them from Herzfeld's.

Results obtained by the Lindet-Courtonne method upon a mixture consisting of 4.9468 grams cane-sugar and 0.2628 gram raffinose $($ total $=1 / \mathrm{s}$ normal) in $20 \mathrm{cc}$. distilled water, were as follows :

\begin{tabular}{|c|c|c|c|c|c|c|}
\hline Original & Result & Raff & ose. & Sacc & rose. & \\
\hline $\begin{array}{l}\text { invert } \\
\text { reading. }\end{array}$ & $\begin{array}{c}\text { on } \\
\text { normal. }\end{array}$ & $\begin{array}{l}\text { (Lin1: } \\
\text { det. })\end{array}$ & $\begin{array}{l}\text { (Herz- } \\
\text { feld.) }\end{array}$ & $\begin{array}{l}\text { (Lin- } \\
\text { det.) }\end{array}$ & $\begin{array}{l}\text { (Herz- } \\
\text { feld })\end{array}$ & \\
\hline -I0.07 & $-25 . \mathrm{I} 8$ & 4.97 & 5.33 & 93.28 & 92.60 & $\begin{array}{l}2 \mathrm{cc} \text {, dilute hydrochlo- } \\
\text { ric acid added every } \\
\text { four to five minutes } \\
\text { and heated five min- } \\
\text { utes additional ; zinc } \\
\text { filtered out. }\end{array}$ \\
\hline-9.25 & -22.89 & 6.47 & $6.8 \mathrm{I}$ & $90.5 \mathrm{I}$ & 89.87 & $\begin{array}{l}\text { The above repeated, } \\
\text { but the zinc not fil- } \\
\text { tered out. }\end{array}$ \\
\hline-7.00 & -17.32 & 10.05 & 10.40 & 83.89 & 83.23 & $\begin{array}{l}\text { Whole to cc. hydro- } \\
\text { chloric acid added } \\
\text { within three min- } \\
\text { utes, and heat ap- } \\
\text { plied twenty min- } \\
\text { utes in all; zinc not } \\
\text { filtered out. }\end{array}$ \\
\hline
\end{tabular}

Result by Clerget method I897. 
These results show that the method is totally unreliable with products of the above composition.

'I he Lindet-Courtonne method was then applied to the molasses having a direct polarization of 50.6 per cent. and which by Clerget's method, using 3 grams char and shaking five minutes, gave 3.58 per cent. raffinose and by the decolorization with I gram zinc, as is proposed, also $3.5^{8}$ per cent. raffinose.

\begin{tabular}{|c|c|c|c|c|c|c|}
\hline \multirow{3}{*}{$\begin{array}{l}\text { Original } \\
\text { invert } \\
\text { reading. } \\
-4.18\end{array}$} & \multirow{3}{*}{ 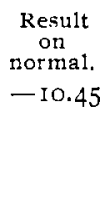 } & \multicolumn{2}{|c|}{ Raffinose. } & \multicolumn{2}{|c|}{ Saccharose. } & \multirow[b]{3}{*}{$\begin{array}{l}\text { Adding hydrochloric } \\
\text { acid every five min- } \\
\text { utes; total heating: } \\
\text { twenty-five minutes } \\
\text { cooling quickly and } \\
\text { filtering out zinc. }\end{array}$} \\
\hline & & $\begin{array}{l}\text { (Lint- } \\
\text { det.) }\end{array}$ & $\begin{array}{l}\text { (Herz- } \\
\text { feld.) }\end{array}$ & (Lin- & $\begin{array}{l}\text { (Herz- } \\
\text { feld.) }\end{array}$ & \\
\hline & & $3.7^{6}$ & 3.91 & 43.65 & $43 \cdot 36$ & \\
\hline$-4 \cdot 35$ & -10.77 & 3.55 & 3.70 & 44.04 & 43.74 & $\begin{array}{l}\text { Adding hydrochloric } \\
\text { acid every four min- } \\
\text { utes i total heating, } \\
\text { twenty-one minutes; } \\
\text { cooling quickly zinc } \\
\text { not filtered out. }\end{array}$ \\
\hline
\end{tabular}

The inversion even on "rest" molasses varies with varying conditions of time, etc. The results, besides varying beyond limits of error among themselves, vary also from the results obtained by the standard method, as shown above, where chars are compared upon molasses.

Perhaps the most instructive result is that shown in the following experiment, where are compared: (I) The strict Clerget method without char; (2) the strict Clerget method with 3 grams of Merck's highest purity char after five minutes' shaking; (3) the Lindet-Courtonne method, adding $2 \mathrm{cc}$. hydrochloric acid every four minutes and heating thirty minutes in all; (4) the Herles method, using I0.6 cc. lead nitrate solution and one-half equivalent sodium hydroxide; (5) the proposed modification to the strict Clerget method, $i$. e., addition of I gram powlered zinc. Each $100 \mathrm{cc}$. of original solution contained I I.46I2 grams pure cane-sugar and 0.814 gram raffinose. It was the intention to secure the same polarization as obtains in ordinary "rest" molasses with a content of 2.5 per cent. raffinose. With the exception of the Lindet-Courtonne method, $50 \mathrm{cc}$. of the original solution were taken for inversion. With the Lindet-Courtonne method, the prescribed $20 \mathrm{cc}$. were used in a $50 \mathrm{cc}$. flask and the zinc volume allowed for. 


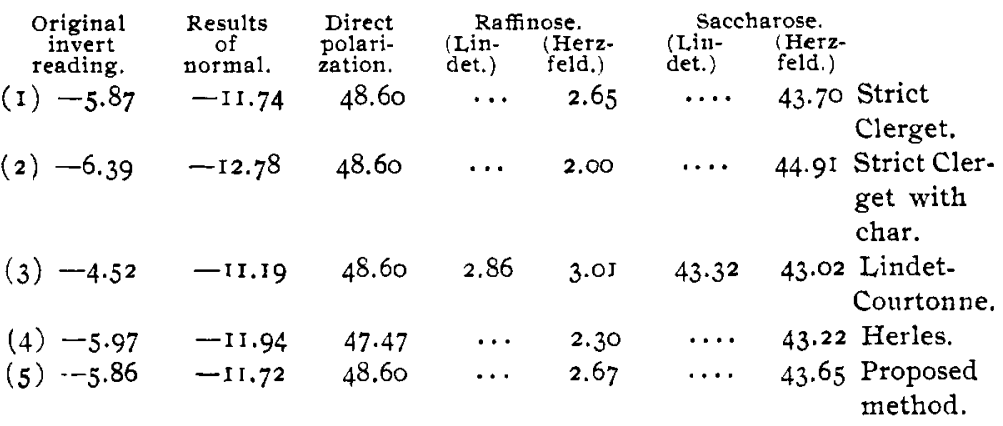

With the strict Clerget method and use of char the increased levo-rotation is very considerable and causes a very notable variation in sucrose and raffinose from the truth. The Lindet-Courtonne method, while not showing such great variation, is still unsatisfactory and does not inspire confidence; furthermore, the writer finds inversion under its conditions more time-consuming than under any other. The modification to Clerget's method that I propose seems to give results concurring with the strict Clerget method, both here and with molasses; also in a later experiment, where the proportion of raffinose is increased.

The method next inquired into is that of Herles, ${ }^{1}$ with the object of ascertaining its action where raffinose is present. No comparison was made of it upon inverted pure cane-sugar solutions.

Herles' chief objection to determinations by inversion as carried out up to that time was, that clarification by means of lead acetate for direct polarization and not for invert, would give wrong results, because optically active substances are precipitated in the operation for direct polarization, which remain in the inverted solution and either retain their whole optical activity or the acid changes it, or perhaps the optical activity is for the first time developed during inversion.

Degener has shown that invert sugar by evaporation, even in racuo, loses its theoretical levo-rotation and finally becomes dextro-rotatory, which, by treatment with hydrochloric acid, according to Clerget, soon takes on its original levo-rotation; hence, it affects only the invert reading.

Herles states that lead nitrate remaining in excess as such has only insignificant action, and Herzfeld admits that the action is

1 Herles, 1890 : "Ueber die Bestimmung des Zuckers durch die Inversionsmethode," Ztschr. d. I'er. fürd. Rübenzuckerind, d. deutsch. Reiches, p. 217. 
small. Herzfeld states that sodium nitrate heightens the polarization and, while admitting that basic leacl nitrate is a remarkable decolorizer, affirms that it carries clown sugar with it, cspecially if the alkali be added all at once, and even a little if it be added drop-wise. Neutral salts, with the exception of the acetates, increase the levo-rotation, but the acetates reduce the free hydrochloric acid and thus lower inverting or hydrolyzing power; hence, Herles was led to consider $\mathrm{PbOHNO}_{3}$ as the most suitable form. He used "a lead nitrate solution of $\mathrm{I} .3856$ specific gravity (or about saturated), and in which I cc. $=0.3$ IO2 lead." This could not be correct, since a stronger solution of lead nitrate, i. e., specific gravity I.4I4, and containing 35 per cent. lead nitrate only contains the equivalent of 0.3094 gram lead.

He distinctly states that the solution should not be alkaline, as lead saccharate would be precipitated and, while proving that resulting potassium nitrate causes increased levo-rotation, belittles it by adding that the solutions are always weak in sugar where much potassium nitrate is formed.

The solution of lead nitrate used for this experiment had a specific gravity of 1.33233 and contained the equivalent of 0.2488 gram lead or 0.398 gram lead nitrate, equaling 29.872 per cent. Accordingly, I cc. of this lead nitrate, to form the stipulated basic salt, will require $\mathrm{I} .202 \mathrm{cc}$. normal sodium hychoxicle, or where the standard alkali has a corrective factor of $I . O 6 I$ as in this instance, I.I33 cc. A normal of molasses was weighed out, and after dilution to about $70 \mathrm{cc}$. the specified quantities of lead nitrate solution added and then the alkali solution gradually and with rotation of flask, when all was carefully diluted to exactly Ioo cc. at $17.5^{\circ} \mathrm{C}$. Io.6 cc. lead solution and $\mathrm{I} 2 \mathrm{cc}$. alliali solution cleared the solution perfectly and left no excess of alkali.

\begin{tabular}{|c|c|c|c|c|c|}
\hline $\begin{array}{l}\mathrm{Pb}\left(\mathrm{NO}_{3}\right)_{2} \\
\text { solution. } \\
\quad \mathrm{cc} .\end{array}$ & $\begin{array}{l}\text { NaOH } \\
\text { solution. } \\
\text { ce. }\end{array}$ & $\begin{array}{l}\text { Direct } \\
\text { reading. }\end{array}$ & $\begin{array}{l}\text { Invert } \\
\text { reading. }\end{array}$ & Raffinose. & Saccharose \\
\hline 9.00 & I 2 & 50.75 & --586 & 3.77 & 43.77 \\
\hline$(2) \ldots \ldots 10.60$ & I 2 & 51.10 & --5.86 & 3.85 & 43.98 \\
\hline (3) $\cdots \cdots 12.00$ & I 2 & 50.99 & -5.86 & $3 . \$ 2$ & $43 \cdot 9^{2}$ \\
\hline
\end{tabular}

In samples (2) and (3), considerable lead chloride was thrown down. In such work of Herles as has come under our notice, the absence of very specific directions as to the limits of lead to be used, has left us without much information, and an intimate study 
of the best conditions is not warranted, as the process has the serious defects already referred to.

The direct polarization on the same sample varies quite a little from that where lead basic acetate is used (i.e., 50.6 per cent. pol.) which may be accounted for by the action of the lead salt upon the invert sugar present, which is a trifle less than 2 per cent. In the former table, where the five methods are compared, we have shown a reduction from 48.6 to 47.47 per cent. polarization where basic lead nitrate was used; hence, this is probably more than compensated for by the modified levulose rotation. To recapitulate, the results obtained so far by the different methods upon molasses, we have:

\begin{tabular}{|c|c|}
\hline 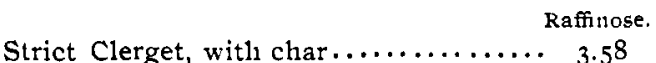 & $\begin{array}{c}\text { Saccharose. } \\
43.97\end{array}$ \\
\hline $\begin{array}{lll} & \\
\text { Proposed method, adding zinc........... } 3.5 & 3.58\end{array}$ & $\begin{array}{l}43.97 \\
43.97\end{array}$ \\
\hline Lindet-Courtonne, varying conditions.... $3.9 \mathrm{I}$ & $43 \cdot 36$ \\
\hline with Herzfeld's formula... $33.7^{\circ}$ & 43.74 \\
\hline Herles' method, applied $\ldots \ldots \ldots \ldots \ldots \ldots, \quad 3.85$ & $\begin{array}{l}43.9^{8} \begin{array}{l}1 / 2 \text { equivalent } \\
\text { sodium hydroxide. }\end{array}\end{array}$ \\
\hline
\end{tabular}

The next experiment shows (I) the absorbent effect of char upon the products of the hydrolysis of pure saccharose and pure raffinose when they are mixed in varying proportions; also (2) results by the proposed new zinc modification to the strict Clerget method, when compared with the strict Clerget method without the use of char.

\begin{tabular}{|c|c|c|c|}
\hline $\begin{array}{l}\text { Direct } \\
\text { reading }\end{array}$ & $\begin{array}{l}\text { Invert } \\
\text { reading } \\
\text { without }\end{array}$ & $\begin{array}{l}\text { Invert } \\
\text { reading } \\
\text { with } \\
\text { chat. }\end{array}$ & \\
\hline 25.62 & -6.62 & -7.01 & $\begin{array}{l}\text { Used } 0.3285 \text { gram raffinose and } 6.1835 \text { grams } \\
\text { sugar. }\end{array}$ \\
\hline 48.60 & -5.87 & -6.39 & $\int 17.1917$ grams sugar \\
\hline 48.60 & -5.87 & $\ldots$ & Proposed zinc modifi- $\left\{\begin{array}{l}\text { and I.22I grams } \\
\text { raffinose. }\end{array}\right.$ \\
\hline 53.40 & -4.58 & -5.57 & ( 7.1917 grams suga \\
\hline 53.40 & -4.57 & $\cdots$ & $\begin{array}{l}\text { Proposed zinc modifi- }\left\{\begin{array}{l}\text { and } 2.442 \text { grams } \\
\text { raffinose. }\end{array} \text { cation. }\right.\end{array}$ \\
\hline
\end{tabular}

The zinc in the presence of the hot hydrochloric acid at $69^{\circ} \mathrm{C}$. has, therefore, absolutely no effect upon the products of the hydrolysis of saccharose and raffinose. It has been found advisable to filter out, by means of a very small tuft of cotton, the residue from the I gram of zinc left after cooling to $20^{\circ} \mathrm{C}$., with quantitative washing, of course, since the continued, slow evolution of hydrogen may disturb proper dilution to the mark. 
The author wishes to add some tests made upon the correctness of Herzfeld's formula for the temperature correction for raffinose :

As A pplied to Hydrolyzed Half-Normal CaNe-Sugar in too cc.

$\begin{array}{ccc}\text { Temperature. } & \begin{array}{l}\text { Dilution. } \\ \text { Original } \\ \text { reading. }\end{array} & \begin{array}{c}\text { Calculated to } 20^{\circ} \mathrm{C} . \\ \text { normal inversion. }\end{array} \\ 17.2 & -17.06 & -32.59 \\ 20.0 & -16.32 & -32.64 \\ 20.9 & -16.07 & -32.59 \\ 21.6 & -15.93 & -32.66\end{array}$

As Applied to Mixture of 12.367 Grams Cane-Sugar and 0.657 Gram RAFFINOSE IN IOO CC. DILUTION.

$\begin{array}{ccc}\text { Temperature. } & \begin{array}{c}\text { Original } \\ \text { reading. }\end{array} & \begin{array}{c}\text { Calculated to } 20^{\circ} \mathrm{C} . \\ \text { normal inversion. }\end{array} \\ 16.4 & -14.40 & -27.00 \\ 20.0 & -13.50 & -27.00 \\ 23.0 & -12.79 & -26.97\end{array}$

It is not advisable to make the polarization at any temperature without the use of the jacketed tube.

Caro, Michigan,

Aprit 22, 1903.

[CONTRIBUTION FROM THE BUREAU OF CHEMISTRY, LABORATORY OF INSECTICIDES AND Agricultural Waters, U. S. Dapt. OF Agriculture, No. 52, - SeNT by H. W. WILEY.]

\section{A COMPARATIVE STUDY OF METHODS OF DETERMINING FORMALDEHYDE.}

BY BERNARU H. SATTH.

Received !une 26,1903 .

THE uses of formaldehyde have widely increased during the past few years. As a disinfectant it has come to be used in enormous quantities by health inspectors, its vapor or a dilute solution destroying many kinds of pathogenic bacteria; as a preservative it is one of the most effective and one of the most convenient to use; it is an important fungicide, the agriculturist finding it a valuable aid in combatting certain plant diseases, while as an insecticide it rids man of those insects, often more plentiful than appreciated, that choose to live in the crevices close to his food or his bed.

With the increasing use of formaldehyde, many new methods have been suggested for its quantitative determination. While some of these are rather difficult of manipulation or have other 